\title{
AS FRONTEIRAS POROSAS DO CONTEMPORÂNEO: UMA BREVE REFLEXÃO SOBRE O ROMANCE BECOS DA MEMÓRIA
}

\author{
Denise Aparecida do Nascimento ${ }^{1}$ \\ Universidade Estadual da Paraíba - CAPES \\ (denablue72@gmail.com)
}

\begin{abstract}
Resumo: O presente trabalho tece uma breve reflexão sobre as fronteiras sociais vividas por alguns personagens do romance Becos da Memória, da escritora Conceição Evaristo, em especial a personagem Ditinha. Tal reflexão procura mostrar como a escritora utiliza a noção de fronteira para expor a condição do sujeito simultaneamente incluído e excluído de nossa sociedade. A partir da década de 1990, Conceição Evaristo surge no cenário literário brasileiro e introduz um modo de narrar que subverte as narrativas estereotipadas sobre o povo negro, principalmente da mulher. Desse modo, importa refletir sobre as fronteiras contemporâneas e suas múltiplas interpretações.
\end{abstract}

Palavras-chave: Becos da Memória; Conceição Evaristo; Fronteira.

Abstract: The present work presents a brief reflection on the social boundaries experienced by some characters of the novel Becos da Memoria, by the writer Conceição Evaristo, especially of the character Ditinha. This reflection seeks to show how the writer uses the border notion to expose the subject's condition that is simultaneously included and excluded in our society. From the 1990s, Conceição Evaristo appears in the Brazilian literary scene and introduces a narration that subverts stereotyped narratives about the black people, especially women. In this way, it is important to reflect on contemporary boundaries and their multiples interpretations.

Keywords: Becos da Memória; Conceição Evaristo; Boundaries.

Resumen: El presente trabajo presenta una reflexión sobre las fronteras sociales vividas por algunos personajes de la novela Becos da Memória, de la escritora Conceição Evaristo, especialmente en lo que se refiere al personaje Ditinha. Esta reflexión busca mostrar cómo la escritora utiliza la noción de frontera para exponer la condición del sujeto que es a la vez incluido y excluido socialmente. A partir de la década de 1990, Conceição Evaristo aparece en la escena literaria brasileña e introduce un modo de narrar que subvierte las narrativas estereotipadas sobre el pueblo negro, especialmente sobre las mujeres. De tal manera, es importante reflexionar sobre las fronteras contemporáneas y sus múltiples interpretaciones.

Palabras clave: Becos da Memória; Conceição Evaristo; Fronteras.

\section{Introdução}

A globalização foi um tema discutido à exaustão na virada do século $X X$ para o XXI em todas as esferas e instâncias das sociedades ao redor do mundo. $\mathrm{Na}$ atualidade, tais discussões já se encontram arrefecidas, mas não dispensadas.

\footnotetext{
${ }^{1}$ Bolsista (PNPD) do Programa de Pós-Graduação em Literatura e Interculturalidade da Universidade Estadual da Paraíba (2016-2018).
} 


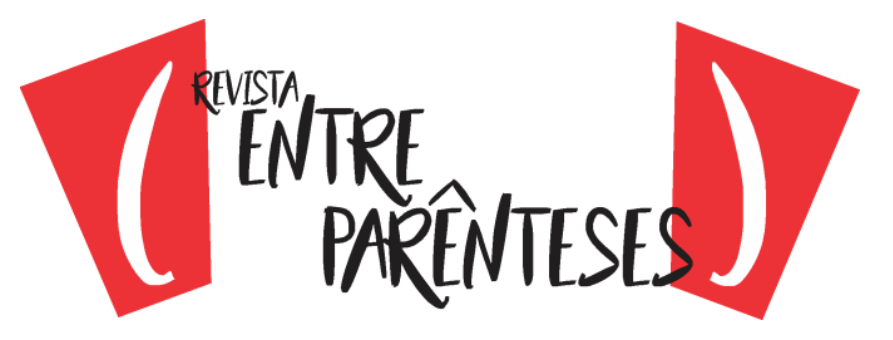

Importa ainda refletir sobre os efeitos desse fenômeno nos meios educacional, acadêmico, político, econômico e cultural.

Por esse prisma, percebe-se que cada vez mais o mundo globalizado nos obriga a perceber as linhas imaginárias que unem ou separam grupos de pessoas diante de distintas circunstâncias. Os conflitos e confrontos territoriais vividos ao longo da história são paradoxais, se por um lado agregam pessoas - instigam o romper de fronteiras, o extrapolar limites —, por outro lado, forçam as separações étnicas e culturais entre grupos. Apesar de o termo "fronteira" ser comumente associado à ideia de limite, cabe ressaltar que ambos guardam significados diferentes.

Limite possui uma concepção territorial mais concreta e geralmente geográfica. Os limites são estabelecidos, na maioria das vezes, por acordos e tratados entre dois ou mais países; já o termo fronteira refere-se a uma linha divisória, seja afirmando, separando territórios ou diferenciando grupos sociais, espaços geográficos, temporais e culturais (MACHADO, 2000). Em outras palavras temos que, os limites muitas vezes são marcados por acidentes naturais (rios, lagos e cadeias de montanhas) e está mais ligado a uma concepção imaginária; já as fronteiras podem ser naturais ou não, e guardam um sentido mais dinâmico e móvel, o que não suporta uma fixação em acordos.

Dessa forma, diante da complexidade do conceito de fronteira, mas entendendo-o como fundamental para se compreender a formação identitária dos sujeitos no texto aqui apresentado, considera-se fronteira como locus do encontro, que ultrapassa os sentidos geográficos, conjugando o simbólico com o metafórico. Leandro Mendes Rocha, em um artigo intitulado O Estado, as Fronteiras e o trinômio índios-deus-pátria! (2003), faz uma reflexão sobre a experiência da vida fronteiriça de sujeitos que se colocam no "limite" entre dois mundos, em suas palavras, a fronteira é:

locus onde se encontram culturas diferentes, sociedades diferentes, economias diferentes, populações diferentes, enfim, onde ocorrem mudanças quantitativas e qualitativas nas vidas das pessoas e populações envolvidas (...) (ROCHA, 2003, p. 96). 


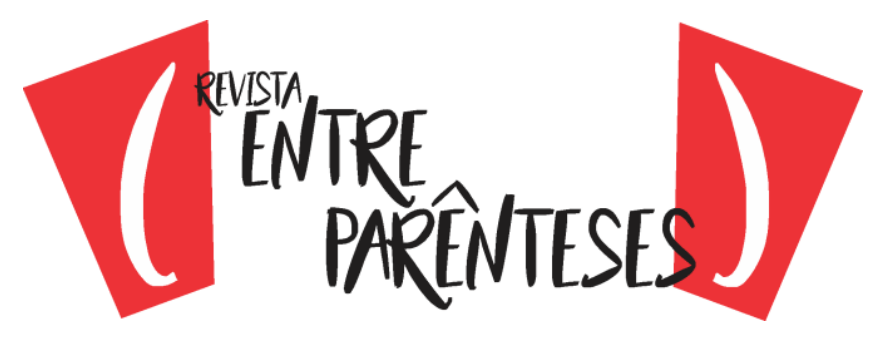

Nesta perspectiva, o texto de Conceição Evaristo proporciona uma ressignificação no sentido que o termo "fronteira" guarda.

\section{Conceição Evaristo: a voz que resgata histórias}

Em Sobre o conceito de História (1985) Walter Benjamin salienta que a História que deveria ser desnudada é a dos vencidos, a das vozes caladas e soterradas em meio aos escombros do passado violento e opressor. A consciência de que a história oficial é uma montagem seletiva de fatos encadeados de maneira linear e ininterrupta, ou seja, de que é uma ficção, possibilita uma revisão histórica por outros ângulos e trazer à tona relatos de pessoas comuns, pequenas e vencidas. De acordo com o pensador, "destruir o passado" significa exterminar com algo que é falso ou enganoso, mas não pelo simples fim; ao contrário, é a partir da ruína, é recolhendo os "cacos" que o novo se faz; é no movimento de "destruição restauração - reprodução" (BENJAMIN, 1985) que se dá a redenção do presente.

Recontar a história, transmitir aos mais jovens conhecimentos acerca das coisas do passado e garantir a manutenção da identidade de uma comunidade. Essas são algumas das principais "funções" de uma expressão artística dentro de um grupo específico. A literatura, como tal, assim se configura.

Em geral, quando falamos em manifestações culturais brasileiras de matriz negras ou africanas, invariavelmente nos vêm à cabeça expressões corporais presentes nos jogos e danças realizadas em ritos religiosos, tais como: a capoeira, o jongo, o bumba-meu-boi, entre de matriz africana, mas isso não é tudo. Aqui vale lembrar que o continente africano acolhe uma grande variedade de culturas, e cada uma delas resguarda um conjunto de manifestações artísticas que preservam dialetos, tradições e identidades específicas de cada grupo.

Desse modo, cabe ressaltar a arte de contar histórias como uma das heranças mais difundidas na cultura brasileira. A força da palavra e a oralidade são instrumentos primordiais na tarefa de educar, transmitir e garantir a manutenção da tradição e da identidade cultural. A contribuição da mulher negra para a riqueza do 


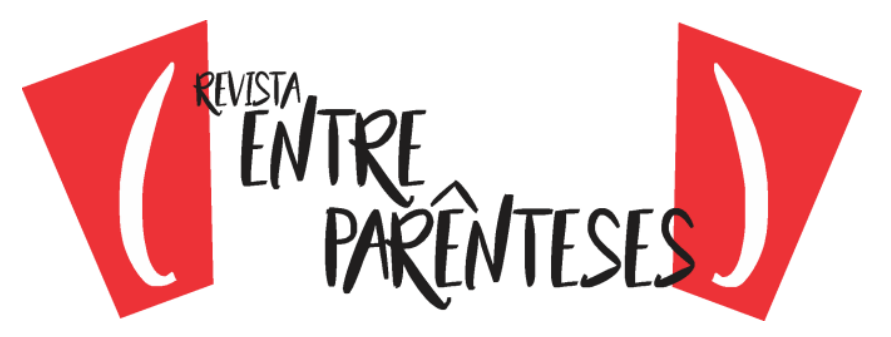

Brasil passa por esse viés, o uso da palavra; vai além do serviço braçal, nos campos de plantações, nas lavouras e principalmente, nos trabalhos domésticos.

No Brasil, é difícil falar em vozes subalternas desveladas sem pensar em Carolina Maria de Jesus, embora o registro oficial aponte o romance Úrsula (1859), de Maria Firmina dos Reis como sendo o primeiro livro de autoria negra feminina brasileira. Foi com o livro Quarto de despejo: diário de uma favelada (1960), que Carolina $M^{a}$ de Jesus iniciou, no Brasil, aquilo que mais tarde viria a ser uma nova tradição narrativa: através do discurso da periferia e dos marginalizados, romper com o silêncio que a condenava e expor as feridas que a sociedade teimava em esconder.

É relevante lembrar que nossa histórica origem escravocrata condenou e ainda condena milhares de mulheres negras brasileiras a um mundo de servidão (em um sentido amplo) que vai desde o trabalho doméstico - para muitas um arremedo de escravidão -, até o servilismo ao marido e filhos, sem muitas expectativas de mudanças. Nessa perspectiva, a literatura apresenta-se como um caminho para os sujeitos femininos produzirem suas próprias subjetividades, já que, na luta pela sobrevivência, as pessoas reinventam, reconstroem e atribuem novos significados à própria identidade continuamente.

É propício introduzir o importante papel da escritora Conceição Evaristo na tarefa de regatar e difundir uma produção literária de autoria feminina e negra. Conceição Evaristo nasceu em 1946, numa favela situada no alto da Avenida Afonso Pena, uma das áreas mais valorizadas da zona sul de Belo Horizonte. Com o tempo, barracos e moradores foram sendo removidos, a avenida ganhou um prolongamento, novos prédios se ergueram e os becos e vielas da infância tiveram que se alojar na memória afetiva da futura escritora. Conceição estudou em escolas públicas da capital mineira, mas só terminou o antigo Curso Normal aos 25 anos. Trabalhou como cozinheira, arrumadeira e lavadeira para algumas famílias tradicionais da cidade; muitas dessas famílias chegaram a desencorajar seus planos 


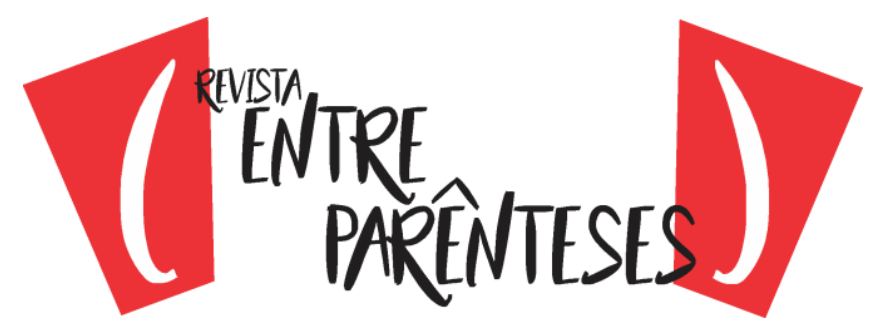

de avançar nos estudos. Em depoimento a Eduardo de Assis Duarte a escritora afirma2:

Enquanto trabalhava como doméstica e após concluir o Curso Normal, eu sonhava em dar aula em Belo Horizonte. Mas aí entra uma questão séria. Em 1971, não havia concurso para o magistério e, para ser contratada como professora, era necessário apadrinhamento. $\mathrm{E}$ as famílias tradicionais para quem nós trabalhávamos não me indicariam e nunca me indicaram...

Em 1973, Conceição mudou-se para o Rio de Janeiro onde se formou em Letras pela UFRJ. É mestre em Literatura Brasileira pela PUC/RJ e doutora em Literatura Comparada na mesma instituição. Em sua dissertação de mestrado, a autora afirma que "a literatura negra é um lugar de memória" (BRITO, 1996, p.24), e nesses termos ratifica a importância de sua produção literária para o grupo que representa.

Evaristo despontou no cenário literário em 1990 publicando no livro Cadernos Negros de número 13. Desde então, sua produção literária tornou-se profícua nacional e internacionalmente, com romances e contos traduzidos para vários idiomas. Seus livros resgatam a história do povo negro e o desvela como um grupo capaz de ricas produções literárias e com voz própria. Interessa ressaltar a forma como Evaristo constrói espaços e legitima os relatos desse grupo menor presente na literatura brasileira. As expressões literárias da escritora constituem um relevante locus de negociação de identidades, culturas e imaginários nacionais; pois segundo Paul Ricouer (1985) quando pensarmos em História - e História da nossa formação -, o termo "abrangerá não só a história narrada quer ao modo histórico, quer ao modo da ficção, mas também a história feita e padecida pelos homens" (RICOUER, 1985, p. 432).

Os trabalhos de Conceição Evaristo, além de desmontarem estereótipos formulados, principalmente sobre a mulher negra, insistindo em mantê-la na cozinha e afazeres domésticos - como se nada mais fossem capazes de fazer - , buscam

2 Depoimento de Conceição Evaristo concedido a Eduardo de Assis Duarte em 2 de março de 2006. C.f. Referências Bibliográficas. 


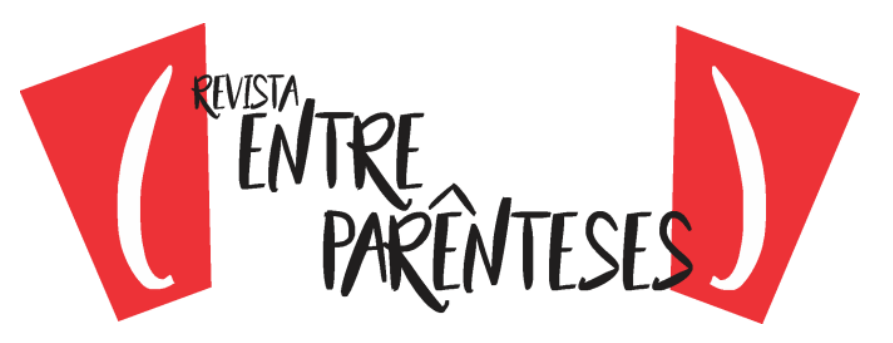

desvelar aquilo que Jessé Souza (2006) chama de 'miopia da percepção ', ou seja, mostrar uma realidade social desigual e naturalizada da pobreza e do racismo. Em outras palavras, as leituras dos romances de Conceição Evaristo, aqui especificamente, Becos da Memória, evidenciam que as desigualdades que cercam o sujeito negro são produções de uma sociedade elitista que fez, e ainda faz da diversidade sócio-racial o objetivo de manter diversas formas de escravidão e exploração.

No Brasil a diferença étnica não decorre de nenhuma fatalidade histórica, apesar da perturbadora naturalidade com que a sociedade a encara, mas sim da manutenção de um poder pré-estabelecido. Encobrir ou sufocar a realidade da desigualdade social brasileira, tanto como da diferença racial é uma prática com origem nos primórdios da colonização. No Brasil existe este histórico errôneo em relacionar essas duas categorias (classe/etnia). Não há dúvidas de que tal correlação existe, mas faltam argumentos capazes de responder como, em determinado momento da História, a construção social passou a ter como base a cor da pele dos sujeitos e daí a condená-los a um sistema impositivo de desigualdades.

A confusão entre desigualdade social (o fator 'ter'), com diferença racial (o fator 'ser') é também disseminada por várias instâncias, e principalmente promovida pela mídia em geral, na discussão política chegando ao ambiente acadêmico, cria a ilusão de que a causa da desigualdade social brasileira é racial e ponto. Como não é possível apontar um aporte interpretativo seguro, que especifique uma hierarquia das causas da desigualdade, a variável racial é percebida, tendencialmente, como um dado absoluto e não como um dos elementos que explicam a especificidade de nossa desigualdade.

A necessidade em externar a condição de subalternidade que vive historicamente o negro no Brasil, impulsiona o trabalho de Evaristo. Conforme afirma em depoimento no artigo Da grafia-desenho de minha mãe, um dos lugares de nascimento de minha escrita (2007), sua escrita veio obrigatoriamente da "função utilitária" da palavra ao tecer a lista de roupas limpas a serem conferidas antes de devolvê-las às patroas; do registro diário dos acontecimentos importantes feitos por sua tia ou do gesto ancestral da mãe em desenhar "um grande sol, cheio de infinitas 


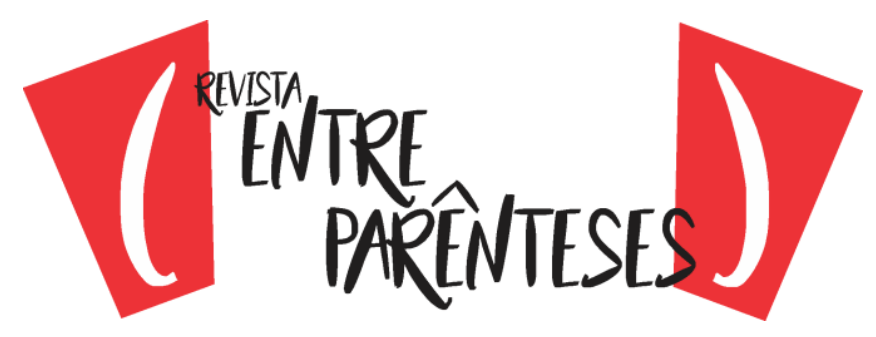

pernas" em dias nublados.

Com um olhar bem atento e crítico, Evaristo se expressa pela ficção, nãoficção e também pela poesia, dessa forma, com a tomada da palavra, a autora leva o leitor a um gesto de desregramento e de desacomodação, e o torna um sujeito questionador e ativo, o faz romper com o silêncio e preencher o "vazio" de sua história, conforme Michelle Perrot:

Os dominados podem sempre esquivar-se, desviar as proibições, preencher os vazios do poder, as lacunas da História. Imagina-se, sabe-se que as mulheres não deixaram de fazê-lo. Frequentemente, também, elas fizeram de seu silêncio uma arma. (PERROT, 2005, p.10).

Quebrar os silêncios, retomar as palavras são os primeiros sinais do romper de fronteiras e subversão das "normas". Os personagens criados por Evaristo transgridem regras, normas socialmente inscritas e reescrevem suas histórias.

No romance Becos da Memória, do grande número de personagens que Evaristo elenca, destacam-se alguns nomes que cruzam fronteiras sociais diárias e emprestaram suas qualidades em favor dos outros; são personagens que tentaram amenizar dores e sofrimentos dos mais próximos e por isso ocuparam espaços diferenciados, nomes como os de Bondade, Vó Rita e Negro Alírio vem à tona no rol dos solidários.

Além das mazelas e do lugar compartilhados, esses personagens se irmanam também num "espaço outro" diferenciado em "desconformidade com os [nossos] espaços desarrumados e mal construídos." (FOUCAULT, 2005, s/p), eles buscam organização no caos da favela. Mas de todas as personagens que compõe a galeria de Becos da Memória, talvez Ditinha seja a mais representativa em viver o conflito de cruzar fronteiras.

\section{Ditinha entre dois mundos: cruzando as fronteiras}




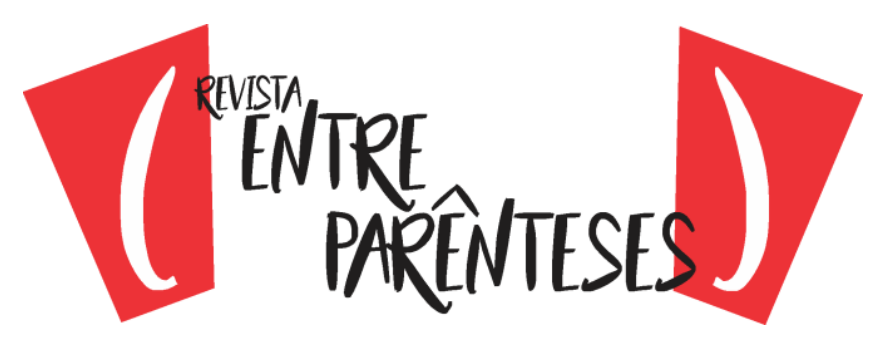

Becos da Memória é o segundo romance de Conceição Evaristo, foi escrito em fins dos anos de 1970 e início de 1980, e somente publicado em 2006. Vale esclarecer que consideramos a história de Becos da Memória um desdobramento ficcional da história real da autora.

A narrativa gira em torno da remoção de várias famílias de uma favela localizada no centro de Belo Horizonte. As autoridades e a empresa responsável pela desocupação criaram situações de profunda angústia entre os moradores do local, fazendo com que muitos recordassem da própria trajetória até chegarem ali. Dessa forma, o enredo não segue uma ordem cronológica, o tempo narrativo vai se desenvolvendo conforme o desenrolar da história do personagem em foco.

Em Becos da Memória, o espaço da favela aparece como produto de uma construção coletiva, mas que agrupa projeções subjetivas; funciona conforme o jardim foucaultiano - um microcosmo de pequenos mundos. Cada barraco, cada família carrega em si um mundo paralelo, compartilham a miséria e as mazelas do cotidiano, mas preservam mundos e sofrimentos particulares.

No início do livro, Evaristo afirma que a escrita do romance é uma forma de homenagear a todas aquelas pessoas que se "amontoam" dentro dela - pessoas reais que compartilharam os desassossegos da infância - e ao mesmo tempo é um exercício de criação, é uma "ficção inspirada" na "ambiência da favela". Dominique Maingueneau em $O$ contexto da obra literária, afirma que:

Na realidade, a obra não está fora de seu contexto biográfico, não é o belo reflexo de eventos independentes dela. Da mesma forma que a literatura participa da sociedade que ela supostamente representa, a obra participa da vida do escritor. O que se deve levar em consideração não é a obra fora da vida, nem a vida fora da obra, mas sua difícil união. (MAINGUENEAU, 2001, p. 46).

As palavras de Maingueneau reforçam nossa afirmação em considerar a escrita do romance como uma criação ancorada em base autobiográfica. A principal voz que se faz ouvir na narrativa é a da personagem Maria Nova, uma espécie de alterego de Evaristo, que também é Maria. A voz da menina entrelaça-se à voz da autora em diversas situações; por exemplo, quando a menina relata as conversas com o personagem Bondade, na verdade esses fatos aconteceram com a escritora; 


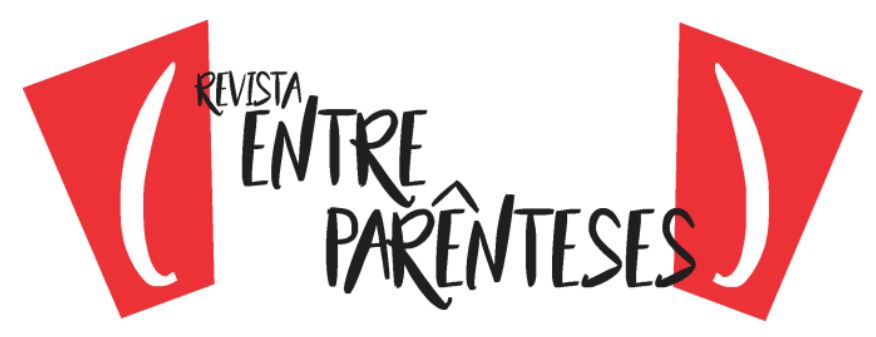

o próprio Bondade foi um sujeito que existiu na favela de Conceição Evaristo, assim como o Tio Totó e mãe Joana (esse é o nome da mãe da autora). Esses elementos sugerem o toque autobiográfico nesse percurso memorialístico que se instala entre 0 real e o ficcional na construção do romance.

Das lembranças da autora emergem figuras inesquecíveis, tais como: a prostituta Cidinha-cidoca-rabo-de-ouro; Tio Totó - homem velho colecionador de perdas; Maria Velha - terceira mulher de tio Totó e tia de Maria Nova; Mãe Joana mãe de Maria Nova, depois de tanto sofrer só sorria por dentro; a Outra - figura fantasmática que se esgueirava pelas sombras dos becos; o Buracão - representa o vilão que expulsa os moradores da favela ou engole aqueles que teimam em ficar. Além daqueles não são nomeados e, no entanto, pertencem a esse grupo de excluídos: são os bêbados, as putas, os malandros e as crianças vadias que habitam as memórias da autora.

Bondade é uma das figuras que bem ilustram essas afirmações acima, a autora o descreve como sendo "um homem pequeno, quase miúdo, não ocupava muito espaço." (BM, p. 38) ${ }^{3}$, e fazia justiça ao apelido carinhoso. Bondade ajudava a todos, estava sempre aqui e ali sem pouso certo já que não possuía barraco no morro, mas em qualquer casebre que chegasse encontrava um cantinho para dormir. Ali ele participava dos dramas e dos parcos momentos de alegria daquela família que o acolhia, além de dividir com esses o pouco que carregava nos bolsos: "...Bondade tinha sempre um trocadinho. Era um leite que ele comprava, um remédio que trazia, um pão que não se teria hoje." (BM, p. 39). O desejo de diminuir o sofrimento dos outros era o que movia Bondade.

Já a velha Rita representava o colo materno para os moradores da favela pois "no coração de Vó Rita tinha espaço para todos e para tudo." (BM, p. 67). Ela era uma mulher grande, gorda e tinha um vozeirão; ela foi responsável por trazer ao mundo muitos dos que viviam na favela:

3 Doravante as citações extraídas do livro Becos da Memória conterão apenas as iniciais BM, seguidas dos números das páginas. 


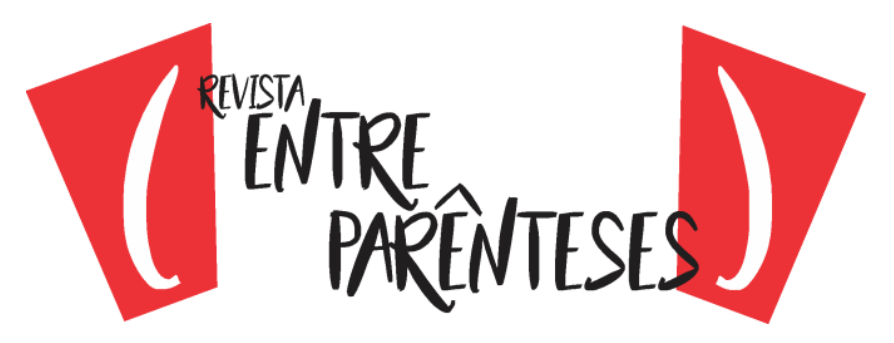

Muito marmanjão e marmanjona haviam sido neném nas mãos de Vó Rita. Todos gostavam dela. Quantas vezes um fuzuê estava armado e, se ouviam a voz de Vó Rita por perto, cada contendor tomava o seu rumo. Não era preciso ela dizer nada. Era só ouvir a voz de Vó Rita que o valentão ou a valentona se desarmava todo. $O$ amor de Vó Rita desarmava qualquer um. (BM, p. 67)

E foi pensando no bem de todos que Vó Rita se sacrificou ao acolher a personagem nomeada como "Outra" - portadora de hanseníase e, portanto, rejeitada pela família e toda a vizinhança - para evitar que a Outra fosse banida daquele núcleo sem perspectiva de abrigo ou socorro, Vó Rita cruzou a fronteira da tolerância e a protegeu, e nesse gesto abriu mão de ajudar nos partos e afastou de si o aconchego dos outros irmãos, mas não perdeu o respeito, nem a admiração conquistados por seu imenso coração, afinal de contas: "Todo mundo sentiu, porém todos entenderam . A única pessoa capaz de acolher a Outra só seria ela. Só Vó Rita tinha coração tão grande! Só Vó Rita não deixaria nunca a Outra tão em meio à solidão." (BM, p. 82).

Deste grupo de personagens generosos, Negro Alírio também chama atenção, pois sua história de vida foi marcada pelos silêncios impostos pelo coronelismo, resquício de escravidão, e das diversas violências que a família vivenciou. Ao crescer e se instruir, se libertou daquele lugar, Negro Alírio reuniu forças para rebelar-se contra o sistema de escravidão que ainda vigorava tanto na fazenda em que vivia como no meio urbano.

$\mathrm{Na}$ favela a história era bem outra, o rapaz circulava pelas intimidades dos outros sempre com a intenção de ajudar, percebia sua vida enredada com as gentes necessitadas do local, mas não subtraída; pelo contrário, foi com base nesta realidade que ele instigava os olhares leigos dos companheiros a perceberem os direitos que Ihes eram furtados pelos patrões, ao mesmo tempo enchia o rapaz de um senso de obrigatoriedade, sentia-se responsável pelo bem estar de todos que estavam a sua volta, afinal havia:

... mil lutas que estavam acontecendo na favela e que ele se sentia comprometido com elas. Era preciso lutar pelo direito de não sair de onde estavam. Era preciso arrumar um advogado da justiça gratuita 


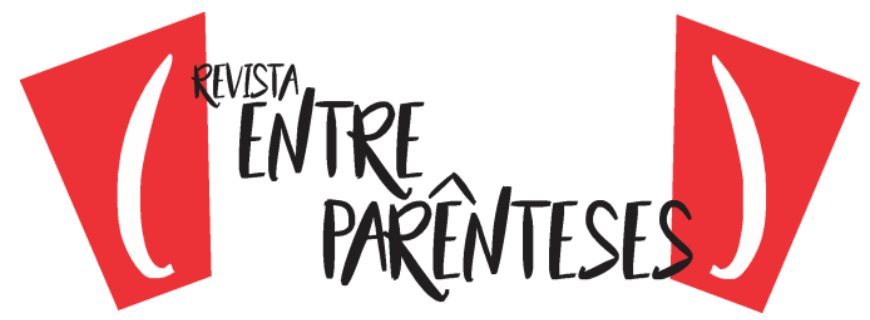

para Ditinha. Ela ainda estava presa ainda [sic]. O Zé da Mercês havia se acidentado no trabalho e os patrões estavam enrolando o homem. Havia ainda os problemas das crianças que, com 0 desfavelamento, perderam as vagas nas escolas ao se mudarem no meio do ano e não encontravam vagas nas escolas próximas para onde iam. (BM, p.134).

Por intermédio dessas ações, Negro Alírio acreditava subverter a organização caótica do espaço em que estavam inseridos e proporcionava aos companheiros um mínimo de dignidade criando um espaço de compensação.

São muitos os personagens que transitam pelas ruelas e becos da favela, uma gama de "gente supérflua" 4 lembradas ou recriadas por Evaristo, entre elas está Ditinha, uma mulher negra e jovem de "29 anos" (BM, p. 99) ${ }^{5}$, mãe solteira que sustentava os três filhos e o pai paralítico, tinha ainda uma irmã mais nova que se prostituía pelo centro da cidade e passava dias fora da favela.

Ditinha trabalhava como empregada doméstica em um bairro rico próximo à favela: "não era grande a distância entre a mansão da patroa e o barraco de Ditinha. O bairro nobre e a favela eram vizinhos." (BM, p. 94). Seguindo o paradoxo do progresso global as distâncias são relativas, nos grandes centros as favelas encontram-se do outro lado do muro dos condomínios.

Era por conta do trabalho que Ditinha cruzava as fronteiras do visível e do invisível social todos os dias. Sentia o fosso que a separava de uma vida mais digna; quando saía do trabalho tentava adiar a volta para casa sentia-se: “... cansada, humilhada" (BM, p. 96). Olhava seu barraco sujo com teias de aranhas, picumãs e roupas amontoadas pelos cantos, comparando com a casa da patroa o fosso ficava maior. Sentia com mais vigor o espaço de exclusão em que realmente vivia.

O drama íntimo de Ditinha começou quando ela teve a oportunidade de se aproximar e de tocar as joias da patroa e por alguns segundos sentiu o gosto do luxo, o sabor de um mundo ao qual não pertencia, embora o frequentasse

\footnotetext{
${ }^{4}$ A expressão 'gente supérflua' é usada por Zygmunt Bauman para definir pessoas excluídas do sistema econômico e produtivo da sociedade, assim: "...desde o início, a modernidade produziu 'gente supérflua' - no sentido de que é inútil, de que suas capacidades produtivas não podem ser exploradas de maneira profícua (...). É uma gente sem perspectivas, que nenhum esforço de imaginação poderia introduzir numa sociedade organizada." (BAUMAN, 2009, p.80).
} 


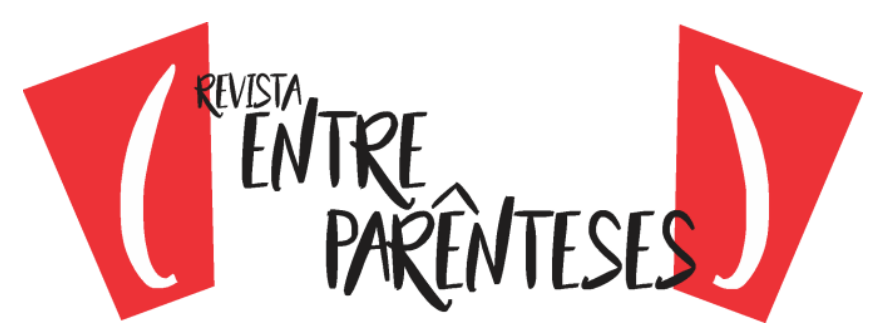

diariamente. Sentindo-se impotente por sua miséria, em um gesto de loucura, roubou uma joia daquelas. Roubou porque introjetou os estereótipos que a sociedade difundia sobre a mulher favelada; comparando-se à patroa, Ditinha sentiase feia, menos feminina e maltratada.

Já em casa arrependeu-se do ato, sentiu vergonha e sem saber o que fazer com o objeto, saiu a perambular pela favela que "era grande e toda recortada por becos. Alguns becos tinham saída em outros becos, outros não tinham saída nunca" (BM, p. 111). A imagem de becos que desembocam em outros becos em uma sucessão circular expõe o cotidiano dos moradores das favelas, encurralados na triste realidade labiríntica e sem perspectivas.

Para Zygmunt Bauman no livro Confiança e medo na cidade (2009), quando o sujeito chega ao ponto de não mais ter esperança de mudança de vida, de evoluir, o sujeito já está na zona do underclass, em suas palavras:

Ser underclass significa estar definitivamente fora do sistema de classes; portanto, não é alguém de uma classe inferior, alguém que está lá embaixo, para quem - obsevem - ainda existe uma escada, e podemos acreditar que conseguirá subi-la, se receber ajuda. Ser underclass significa estar fora, excluído, não servir para nada. (BAUMAN, 2009, p. 83).

Ditinha havia chegado ao fundo do poço e, certa de que pagaria pelo delito, decidiu por se livrar do objeto jogando-o na fossa atrás do barraco. O odor da urina e das fezes foi o gatilho para fazer a mulher perceber que roubar a joia de nada ajudou a melhorar seu "status" de favelada, pelo contrário, reforçou a imagem do comportamento desviante do morador da favela, porque esse era, e ainda é, o estigma da vida deles.

Ditinha foi presa e tempos depois, após cumprir pena, voltou para a favela; afinal a família dela continuava por lá. Contudo, continuou encarcerada em uma prisão voluntária: se escondeu de todos, não saiu de casa para nada, apenas a família e Maria Nova souberam de sua volta e the deram o apoio necessário para prosseguir. A vida seguia, o mundo real insistia, não havia como negá-lo. Mas podia se negar a ele. 


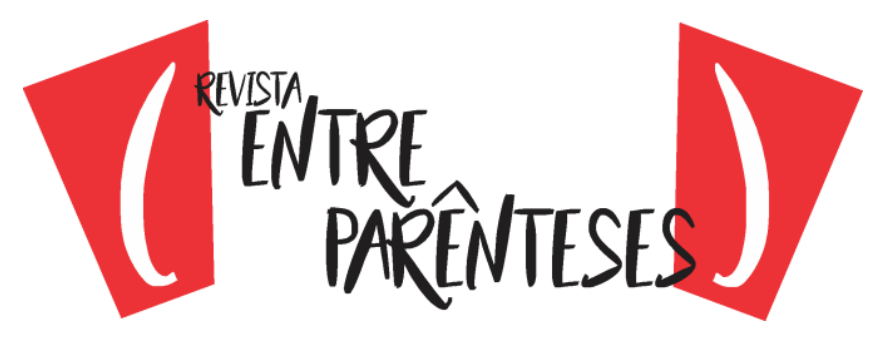

Desvela-se aqui mais uma fronteira cruzada por Ditinha. Embora, pelo senso comum, os moradores das favelas sejam classificados como desviados, Ditinha frequentava e conhecia dois mundos com regras a serem seguidas; portanto, assim que infringiu as "regras" sentiu com mais intensidade as sanções impostas tanto pelas autoridades socialmente legitimadas, quanto por aquelas autoimpostas por sua consciência.

Viver em condição subalterna é realidade de muitas mulheres ao longo da história, embora possam chefiar a família, muitas conhecem o sabor amargo da submissão e da desvalorização. Conhecer os dois lados do fosso social torna Ditinha mais inferiorizada. Eurídice Figueiredo aponta que:

Mulheres subalternizadas, discriminadas em razão da etnia, da classe social, do gênero, elas sofrem todo tipo de desprezo da sociedade, mas resistem, cuidando sozinhas da prole, porque seus homens morrem ou desparecem. Forçadas a viver numa sociedade que as ignora ou descarta, elas não conseguem se inserir de maneira adequada, tornam-se migrantes, tentando sobreviver, em condições miseráveis. (FIGUEIREDO, 2013, p.157-158).

Apesar das situações negativas narradas por Evaristo, vale lembrar que, por intermédio dos personagens, ela mostra que o subalterno já pode se rebelar e se fazer ouvir. Com sua escrita Evaristo responde a já clássica pergunta da teórica indiana Gayatri Spivak: Pode o subalterno falar? (2010) e mostra que sim, o subalterno pode e deve falar. Para Spivak o subalterno não pode falar, não por incapacidade, mas por não haver um "canal" que ligue a voz daquele que fala a um ouvinte. Por esse prisma, Evaristo realiza exatamente o oposto do pensamento de Spivak, ela não só toma a fala como abre espaço para que outras vozes menores possam se manifestar.

A escrita de Evaristo dialoga com a de Carolina Maria de Jesus, escritora que nos fins do ano de 1950, começou a registrar o descaso e o abandono das autoridades e governantes para com os moradores da favela do Canindé, em São Paulo, com o intuito de denunciar a toda sociedade. 


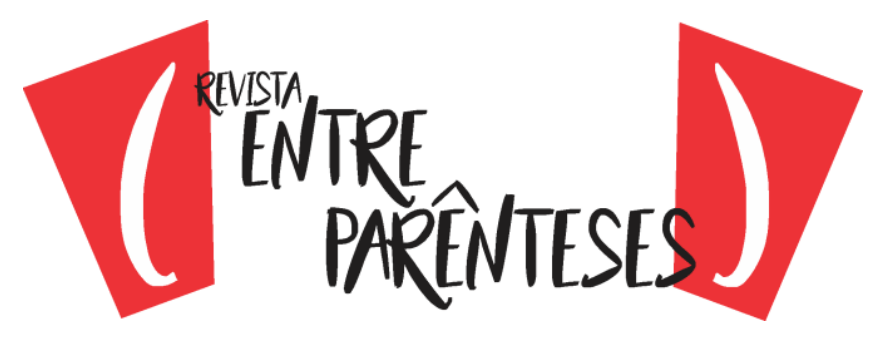

Uma das maiores contribuições de Carolina está em seu gesto pioneiro de mostrar ao mundo que a favela não é apenas o espaço isolado, desprovido de regras, gerador de extrema violência, além dos clássicos problemas socioeconômicos e de infraestrutura. Da favela surgem vozes retumbantes que lutam por tornar visível esse espaço.

Nesse traço, muitos escritores nascidos e moradores nas favelas, despontam no cenário artístico empenhados em mostrar a nova face da periferia. Nomes como o de Paulo Lins, morador da favela Cidade de Deus ganham destaque. Lins foi revelado no meio literário brasileiro em 1997 com o lançamento de seu livro Cidade de Deus, nele o autor faz uma incursão pelo conjunto habitacional, narrando fatos ocorridos desde os anos de 1960, considerados pelo autor, como a época em que os crimes que aconteciam por lá eram pequenos se comparados aos dos anos de 1980 e 1990, quando a violência se tornou generalizada em função do domínio do tráfico de drogas.

Outro nome revelado por intermédio da escrita periférica é o de Ricardo Ferreira da Silva, o Ferréz, aliás foi ele quem cunhou o termo "marginal" que hoje designa a escrita que vem da perifieria. Ferréz nasceu e ainda vive na favela do Capão Redondo, zona sul de São Paulo; é autor, rapper, crítico cultural e ativista social. Escreveu o livro Capão Pecado (2005), onde retrata o cotidiano violento no conjunto de favelas que compõe aquela região. Nele o autor descreve cenas que ele e tantos outros moradores viram e ouviram no convívio diário com a falta de comida, emprego e melhores condições de moradia.

Carolina Maria de Jesus, Conceição Evaristo, Paulo Lins e Ferréz entre tantos outros nomes se irmanam no trabalho de desvelar uma periferia produtiva, rica em sua diversidade cultural - por ser um lugar que abriga pessoas oriundas de diversas partes do país - e ainda assim, é negligenciada pelas autoridades.

\section{Considerações finais}

Becos da Memória é uma história coletiva de nós, é um coro de vozes silenciadas e fadadas ao esquecimento da sociedade e dos demais órgãos públicos. 


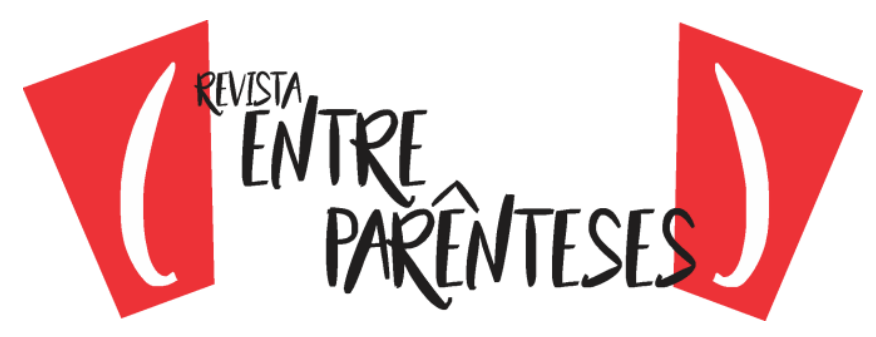

Conceição Evaristo revela nesse romance, histórias de vida dos habitantes de uma favela com traços bem próximos à que viveu em sua infância.

No romance, Evaristo dá vida a vários sujeitos marcados pela pobreza, unidos pela condição de formarem um grupo de rejeitados socialmente, mas que não podem evitar o conflito de cruzarem a linha da (in)visibilidade diária, porque são feridos sempre que deixam o mundo do conforto e da abundância onde prestam serviços para adentrar em suas realidades miseráveis. Assim, a personagem Ditinha representa muitas mulheres pobres, mães solitárias ou chefes de família que se tornam vítimas "naturais" de um mundo preconceituoso e machista, que apenas as exploram.

Romper fronteiras, efetuar mudanças, buscar referências e "aceitar" o outro são os desafios contemporâneos. Portanto, denunciar a submissão e desvelar a relação de subalternidade entre os sujeitos foi uma das molas propulsoras dessa escritora que vê a fronteira para além dos sentidos físicos e geográficos.

\section{REFERÊNCIAS}

BAUMAN, Zygmunt. Confiança e medo na cidade. Trad. Eliana Aguiar. Rio de Janeiro: Zahar, 2009.

BENJAMIN, Walter. O narrador - Observações sobre a obra de Nikolai Leskov. In.: Textos escolhidos. 2ed. Trad. Modesto Carone. São Paulo: Abril Cultural, 1983, p. $57-74$.

BRITO, Maria da Conceição Evaristo de. Literatura Negra: Uma poética de nossa afro-brasilidade. Dissertação de Mestrado, PUC/RJ, 1996.

DUARTE, Eduardo de Assis. O Bildungsroman afro-brasileiro de Conceição Evaristo. Revista de Estudos Feministas. vol.14 n¹ Florianópolis Jan./Abr. 2006.

EVARISTO, Conceição. Da grafia-desenho de minha mãe um dos lugares de nascimento de minha escrita. In: ALEXANDRE, Marcos Antônio (org.). Representações Performáticas Brasileiras: teorias, práticas e suas interfaces. Belo Horizonte, Mazza Edições, 2007, p 16-21.

FIGUEIREDO, Eurídice. Mulheres ao espelho: autobiografia, ficção, autoficção. Rio de Janeiro: EDUERJ, 2013 


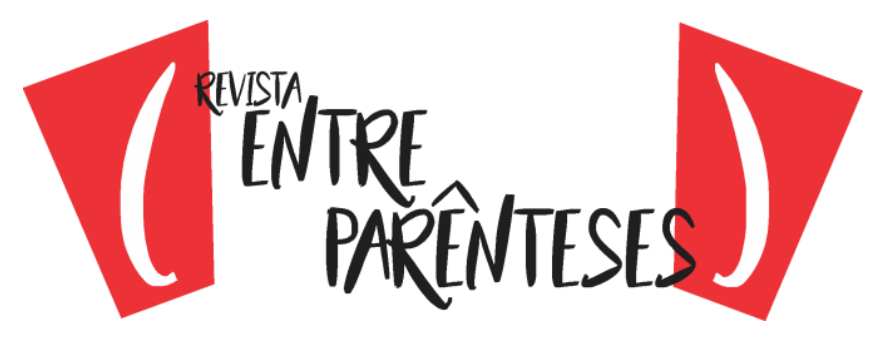

FOUCAULT, Michel. Outros Espaços. Trad. Pedro Moura. In.: Diacritics, vol.16, no1, Primavera de 1986, [2005].

MACHADO, Lia Osório. Limites e fronteiras: da alta diplomacia aos circuitos da ilegalidade. Revista Território, Rio de Janeiro, ano V, no 8, pp. 7-23, jan./jun., 2000.

ROCHA, Leandro Mendes. O Estado, as Fronteiras e o trinômio índios-deus-pátria! In: GUTIÉRREZ, Horacio; NAXARA, Marcia R. C. e LOPES, Maria Aparecida de S. (orgs.). Fronteiras: paisagens, personagens, identidades. Franca: UNESP; São Paulo: Olho D’Água, 2003.

RICOUER, Paul. Temps et récit III. Seuil, 1985, p.432.

SOUZA, Jessé (Org). A invisibilidade da desigualdade brasileira. Belo Horizonte: UFMG, 2006.

SPIVAK, Gayatri Chakravorty. Pode o subalterno falar? Trad. Sandra R. Goulart. BH: Ed. UFMG, 2010.

Recebido em: 25/04/2018 Aceito em: 29/11/2018 